\title{
Group Organizations Among Lawyers
}

\author{
By Herbert Harley \\ Secretary, American Judicature Society, Chicago, Illinois
}

\section{$\mathrm{T}$} THERE is a tradition in the legal profession of a golden age. No living lawyer can testify to the existence of a golden age from personal knowledge. If ever there was such a fortunate era it must have been before the Civil War. However skeptical of tradition we may be, we can admit that for a generation before the Civil War the lawyer was better adapted to his environment than he is now.

In that period the law was relatively simple and static. It is the amazing complexity of twentieth century industrial and social life which has brought about the inundation of statute law and the welter of decisions. Professional training which today would imply mediocrity may have then appeared quite adequate.

The lawyer was not subject to such powerful and insidious influences in that simpler age. There were few private interests strong enough to keep a "house lawyer," one under exclusive retainer on an annual contract. There were no corporations existing to do the traditional work of the office lawyer, advertising for clients and hiring lawyers by the year. The country was expanding rapidly. There was enough practice in most places to provide a living. At any rate, the fratricidal competition of later days, with correspondence courses and proprietary law schools turning out graduates far in excess of community needs, had not yet appeared.

There were always temptations, but with fewer lawyers the position of the lawyer was a conspicuous one and the theory that the court was responsible for the ethical conduct of practitioners was still in working condition. It has validity yet in primitive regions. When lawyers had to rely on a wide range of clientage they were free to refuse embarrassing retainers. There was not the moral overstrain, imposed in these days upon the lawyer who has but one, or two, or at most three clients and must win his suits for his own salvation.

This older profession, limited in numbers and independent in mind and morals, felt some contempt for business. Or, if this is putting it too strongly, let us say that the bar at least exalted the law and its servants. There were few others in the community who could assume the dignity of learning and influence. The lesser competition set the lawyer on a conspicuous level. The earnings which now would seem meager were then ample in view of the respect which the calling compelled.

\section{The Older American Tradition}

It is not safe to go much farther back in the quest for the golden age. In certain of the colonies laws were enacted to prevent the existence of a bar. After the Constitution was adopted there were states in which ignorant laymen attempted to administer justice from the bench. From the first, the American bar had to make its way against hostile philosophy. This explains why it never possessed the organic powers enjoyed in other lands. In Belgium, for instance, the bar asserts its independence of both legislature and judiciary. In all other countries there is an organization of the bar which is all-inclusive and which has effective machinery for maintaining standards. The powers to admit 
to practice and to expel are exercised by the bar itself. In consequence, the bar is primarily responsible for ethical conduct and it is able to discharge this responsibility.

The American tradition is that the bar exists to assist the courts in the administration of justice and hence that lawyers are "officers of the court." This makes the judges responsible. It is obvious, however, that the lawyer's rôle is larger than assisting the court. The lawyer interprets the law without reference to specific conflicts of rights. Many lawyers, indeed, rarely appear in court. And the courts lack the power to acquit themselves of the presumed responsibility. There are numerous "independent" judges but little judicial solidarity. In most states judges are elected and lawyers play a large part in nominating and electing. The power of the judge over the jury has been restricted by statute very generally, a restriction which exalts the position of the advocate.

There must be somewhere in the state or in society power to establish standards of professional conduct with responsibility for enforcing them. It is easy to understand the practical failure of the courts in this field. And it is too delicate a matter for legislative control. An enacted code of rules would merely invite unethical lawyers to devise loopholes in the law.

There remains, then, the matter of professional self-regulation which in other countries has served for centuries to develop and maintain bars which, compared with ours, are free from censure.

As a matter of fact, when the older tradition failed, the bar of the typical state began to move instinctively toward the principle of self-discipline through organization. This movement was slow to begin but has been continuous for forty years and recently has been accelerated by a conviction that the golden age has been succeeded by an age of brass. There are strong indications at this time that the bar is working its way out of chaos and that the future will see conditions very much better than those now prevailing. It is the purpose of this article to trace this development.

\section{Early Attempts to Organize THE BAR}

For fully half our national history there were practically no attempts to organize the bar. The first associations arose in the larger cities, and then, as means for travel were improved and acquaintanceship was extended, state-wide association began. We do not pretend that the avowed purpose was to maintain standards. The leading motive was purely social. The bar was not immune from the modern instinct for organization, though somewhat resistant. There was also the need and the opportunity for establishing honors to mark professional success, something to confer and something to strive for.

An essential need was that of preserving standards, even though unrecognized at the inception of the movement. For lawyers of social inclination and professional pride who joined associations were thus enabled to separate themselves from the unorganized part of the profession upon which public suspicion and reproach rested. Unable to compel a fellow practitioner to be ethical, or even decent, the conscientious lawyer could at least walk on the other side of the street. Perhaps this was done to escape responsibility, but its actual effect was to assume it.

Even the loose and meager association afforded a point for effort. A responsible profession was evolving like a planet from nebular chaos. And 
having presumed, in a measure, to stand for the profession, the associations had perforce to devise means for acquitting themselves.

In 1878 there were eight city and eight state bar associations in twelve states. In this year the American Bar Association was formed by the meeting of seventy-five lawyers residing in twenty-one states. There were then 60,000 lawyers in the United States.

In 1921 the American Bar Association reached a membership of 16,000 . For a number of years every state except Delaware has had its state bar association. Similar bodies exist in Alaska, Hawaii, Porto Rico and the Far East as parts of the system. Over 800 city and county associations are listed by the Conference of Bar Association Delegates, a liason body created in 1916 by the American Bar Association.

\section{The Local Associations}

There is a remarkable similarity among local associations. In all of them membership is open to any lawyer not especially subject to objection. (In the southern states, and in most northern states, Negro lawyers and white lawyers associated with them in practice, are excluded, a reservation which illustrates very well the social basis of organization.) Practically all are seeking growth. There is nowhere any organic relation between the state and local associations, or the state and national, except that in Washington recently the state association has been accepting the entire membership of local associations which conform to its requirements. Elsewhere, a lawyer may belong to any one, or any two, or to all three types in this hierarchy.

The interests of the various associations, as shown by the titles of addresses delivered, is vague and diffuse. Papers are read on trial by jury, on
John Marshall and Daniel Webster, the lawyer's oath and the Monroe Doctrine. There is a disposition to take an interest in the development of law, especially through legislation. Decisions are rarely analyzed or criticized. In many of the local associations the annual or quarterly dinner transcends all other activities. In small cities the local association is perfunctory, rarely meeting except to deplore a death or honor a judge.

In some of the larger cities the associations have for a long time been engaged in definite useful activities. The Association of the Bar of the City of New York is the oldest and strongest. For over eighteen years it has maintained a salaried force to prosecute delinquent members of the profession. The New York County Lawyers' Association has done similar work and in some years the two bodies have devoted $\$ 25,000$ to this odious work.

\section{The Legal Ethics Clinic}

The latter body originated the legal ethics clinic, which is one of the most significant movements in the entire history of the American bar. It grew out of the realization that many minor infractions of standards were due more to ignorance than intention. The development of business was changing the nature of the lawyer's services and the profession was becoming flooded with half-educated young men who had no means for acquiring the professional point of view. Spurred on by necessity these young men often overstepped ethical lines without being aware of it. Not only this, but new situations were constantly arising to which well-informed and conscientious lawyers hesitated to apply established principles, on the theory that no man is a safe judge of his own interests. 
So a committee, headed by Mr. Charles A. Boston, ${ }^{1}$ was created to answer questions and, through the determination of nice points based upon actual facts and the wide publication of questions and answers, a common law of ethics was evolved, which is worth more than a thousand hortative addresses on the sacredness of the lawyer's oath. The success of the legal ethics clinic illustrates very well how needs and responsibilities may be met when organic means exist. The determination of ethical rules is safer in the hands of the bar than in the hands of judges. There is always danger that judicial control may infringe the needed independence of the bar. External control from any source must be resisted on general principles. But when the profession itself determines standards the work is done by those whose personal standards are high and who place the welfare of the bar ahead of any individual interests.

The legal clinic idea has spread to Illinois and will before long be a familiar activity in many states, with a central agency under the auspices of the American Bar Association. It is not directly designed to prevent willful misconduct, but it has a profound influence, notwithstanding. It enables all self-respecting lawyers scrupulously to avoid the appearance of indifference to ethics; it creates a norm of conduct along the frontier of doubtful deportment; it makes for a safe ceremonial; and in all these respects it tends to differentiate the ethical practitioners from the unethical. It throws the burden on the unethical to prove that they are not downright evil.

It is, of course, almost a hopeless thing to take a regiment of raw recruits every year and whip them into

${ }^{1}$ Since its organization, Mr. Boston, Mr. Henry W. Jessup and Mr. Julius Henry Cohen have served continuously in its membership. professional discipline, even through a grievance committee and a legal ethics clinic. The work thus far done has helped, as indicated by the fact that the character of offenses is becoming less grievous, but after all it is more like bailing the boat than stopping the leak. With the low requirements for admission, the bar is receiving youths devoid of culture, because it is easier for such young men to gratify their ambitions in this way than to aspire to professions which require longer preparation. The bar has not been able to compete with the engineering profession, to take a conspicuous example, in attracting men of superior qualifications and training.

The Chicago Bar Association is now devoting about $\$ 10,000$ a year to prosecuting delinquents in support of its grievance committee work.

Local bar associations at times interest themselves in securing the election of judges. That judges should ever owe anything to lawyers is obviously unfortunate, but under our system of judicial selection it is inevitable, and it is far better that the obligation should be to associations working in the open than to individual lawyers. The bar as a whole always wants able and fair judges. In Wisconsin the bar, working in an informal manner, has exerted a powerful influence for a generation in opposition to party appointments and nominations, and it has been, on the whole, a worthy influence. In Colorado an elaborate system of bar primaries is employed to guide voters. The Chicago Bar Association has chiefly justified its existence in the public mind by similar effort, and in 1921 it literally saved an entire bench of twenty judges by fighting a powerful political machine which needed only the judiciary to complete its grip upon city and state government. 


\section{The State Associations}

The state associations are strikingly similar in structure but vary in activity and influence. Their average membership does not exceed one-fourth of the bar. Except in one or two states they meet but once a year, and usually for two days. The president of a state association exercises considerable power through making up a program and appointing committees but, as presidents never serve for more than one year, there is little continuity of influence. Attendance at meetings is pitifully small. The casual attendants exert little influence because they are almost unknown and do not themselves understand methods of work. It is usually difficult to extend membership and collect dues. There is little regulation of the profession. The state body is too remote, its meetings too infrequent, and its funds insufficient. It does not work in explicit coördination with local associations.

The majority of its members never attend meetings and so never have any genuine sense of participating in the duties or responsibilities of the association. In consequence, the organization is kept going by the small clique which has sufficient instinct for cohesion to attend meetings and do the required work. The clique control is not to be blamed under the conditions. It is the inevitable consequence of this loose and partial organization. And yet it is frequently made an excuse by acceptable lawyers for refusing to join.

\section{The American Bar Association}

It is not easy to give a true impression of the American Bar Association in limited space. The theory of exclusiveness controlled for a long time, and still exists in the minds of some of the older members, but the Association has grown and expanded to meet imminent needs until it has become the representative body of the entire profession.

Thirty-one years ago the Association called into being the Conference of Commissioners on Uniform State Laws and still stands in loco parentis to the Conference, which has performed a notable service. From time to time special committees were created and some of them became standing committees and then sections. There are now seven sections which greatly amplify the work of the Association and afford means for intensive effort in technical fields. Members can register in any section and participate in its work, the only limitation being that imposed by conflicts of hours on the program.

So the American Bar Association has gradually accepted heavy responsibilities and, in a measure, has created the machinery for discharging the attendant duties. The general sessions strive to entertain, while the committees and sections engage in serious work, largely in the field of legislation and substantive law.

The trouble with the institution is that it has preserved the town-meeting form of government after becoming continental in scope and membership. Grave danger attaches to this situation. Serious decisions are submitted to voting audiences which vary in numbers and personnel from hour to hour. At one time the question of Negro membership threatened disruption. Later, an attempt to align the Association against the prohibition and suffrage amendments was beaten by only a few votes, when its success would probably have cost the Association heavily. This possibility of things going suddenly awry has necessitated a very close control by the executive committee. This is the familiar story 
of pure democracy gravitating, from its very helplessness, into an oligarchy.

An attempt was made (1913-1916) by a special committee, headed by Col. John H. Wigmore, to reform the organization and create a representative control. It was proposed to unify membership in the state and national associations and restrict legislation to accredited delegates apportioned among the state memberships. The time was not ripe for such. a profound change but Mr. Elihu Root, then president, created as a short forward step the Conference of Bar Association Delegates. This body is composed of five delegates from the American Bar Association, three from each state association, and two from each local. As there are about 800 of the lastnamed kind the Conference would be unwieldy if all should participate. Actual attendance in 1921 was by 210 delegates representing 42 state and 76 local associations.

The Conference became a section in 1919, when there was a revision of constitution; as such it receives an appropriation for its work. Its field is deemed to embrace all matters affecting the profession. This gives it substantially the field in which the organic bars of other nations function. Its range of topics has embraced unlawful practice of the law, bar organization, participation in judicial selection and professional ethics. This is a clear demarcation of field from the topics of national policy, legislation and substantive law which largely engross the attention of the parent organization.

This is not so much because the Association did not interest itself in a way in these subjects as that the Conference, being a representative body, afforded better means for making conclusions effective. It early showed the characteristics of a representative body; it tackled its problems with a view to accomplishment; it was not lured by sentimental or rhetorical considerations.

After several years of preparation the American Bar Association in 1908 adopted its Canons of Ethics. ${ }^{2}$ There had been some previous formulation of canons by state associations but the action then taken gave great impetus and within a few years the state associations, with few exceptions, adopted the uniform draft.

\section{The Nature of the Legal Profession}

This sketch of the state of organization at this time has appeared necessary as a basis for consideration of the fields in which organization should work. The lawyer is a creature of the state. There is no inherent right on the part of any person to act as lawyerto advise or to plead causes for hire. But there is a social necessity for such services and the state meets the need by conferring on certain selected individuals the privilege of practising law and forbids others to compete. The practice of law is so much a public or political function that lawyers are essentially public officers, although they do not draw public pay. The profession constitutes, therefore, a body politic, in this respect differing from other professions.

Americans cannot conceive of a body politic standing independent of government, like the bar of Belgium, for instance. In most states the bar is constituted by force of statute and subject to legislative control. But in a few states the courts have held that the bar is a part of the judiciary and hence legislation affecting it is unconstitutional because of interfering with a coördinate and independent branch of government. These variant

${ }^{2}$ Reprinted on page 254. 
theories appear to differ but little in actual practice.

The bar has powers and, consequently, duties. Its powers are quite clearly defined; its duties less clearly. Its means for performing these duties are slowly evolving.

It is obvious that the proper functioning of the bar, with its complex, delicate and immensely important duties, cannot depend upon compulsion. As is the case with judges, lawyers must be presumed to act mainly from intelligent self-interest and high moral perception, and be amenable to public opinion. In the absence of adequate learning and staunch moral fiber no conceivable power could compel faithful and intelligent service. No legislature could force a recreant bar to serve efficiently. The courts have a little power, but not one of continuous regulation, and judicial control cannot take the place of spontaneous good intentions. Regulation, if there be any, must proceed from the profession itself; it must be instinctive and automatic.

\section{The Mission of Legal Ethics}

This whole matter of ethics is vastly more difficult than is implied by the punishment of acts which are malum per se. The public generally is most concerned with mere honesty and wants only to hold the lawyer to the standard necessary for the lay fiduciary. Unfortunately, an element in the public enjoys seeing a lawyer employ every weapon in the arsenal and is inclined to judge solely by success in winning the particular battle. But the public suffers a thousand times more from less conspicuous infractions of ethics than from plain dishonesty. The lawyer has it in his power to provoke litigation, to keep it alive indefinitely and, in a hundred ways, to bring the administration of justice into disrepute, and yet not commit any offense in the criminal code or be thought unfaithful to his profession.

Nor is the public in a position to be critical concerning ability and training. It must largely take its lawyers at their own professed estimate. A very ignorant lawyer can easily impress a jury or the audience of a courtroom by a show of erudition. And lack of technical skill may cause untold mischief, possibly after the lapse of years.

This is the situation in a measure with respect to all professions. Their practitioners deal in mysteries. They are not safely judged except by their colleagues. And that is why there must be ethical standards for professions.

This essential ignorance and helplessness on the part of the public tends strongly to cause a serious misunderstanding of the most important mission of ethical rules. There is a hasty belief that outsiders, able to work for less pay, are prevented from doing some of the lawyer's work in order to save fees for the lawyer. There is also the assumption that ethical rules exist largely to hamper the young practitioner and prevent him from competing with his elders. It is easy to refute the former assumption, for anybody can be made to understand that lay advice is not only hazardous but that it has back of it no responsibility. A lawyer's reputation is his capital which stands behind his opinions. The latter assumption is a little more involved. Indeed, it is strange that so many lawyers themselves cannot explain why advertising is tabu among lawyers. That is, they cannot formulate a philosophic reason based upon social necessity.

The reason lies in the credulity and ignorance of the public. If advertising is permitted, it is the ability to write a persuasive advertisement that 
will gauge success, rather than legal ability. If solicitation of clients is permitted, there is no end whatsoever to competition in solicitation. If ambulance chasing and hospital solicitation are permitted, the public falls a victim to the least ethical, the least conscientious, the least honest of lawyers.

With these coarser evils still menacing the profession it is too early to throw light on such self-recommendation as is gained through candidacy for office, through holding positions of honor in fraternities and public associations of all kinds. But eventually even these less dangerous and more difficult matters may be brought within ethical regulation.

The need now, and for a long time past, has been imperative to expel lawyers who connive at the fixing of witnesses, the bribing of jurors and court officers and the solicitation of personal injury suits. The situation, perhaps, is not as bad as it has been, but in many places it is still deplorable. These are the raw instances of misconduct, found largely in that portion of the bar which specializes in the defense of criminals. They could be curbed by the courts. In Detroit, when a unified criminal court was established in 1920, the shyster was tamed in a single day. Criminal defense has largely shifted to reputable practitioners in that city. But, generally, the judges are too dependent to exert any controlling influence, and in many inferior city courts they are themselves recruited from a doubtful element.

\section{A Step in State Examining Boards}

Good service depends on knowledge as well as character. A lack of either essential threatens a loss of rights or the miscarriage of justice. Legal knowledge can be quite accurately tested by examinations and no person should be admitted to practice until he has given proof of a degree of mastery of the law. But until the last twenty or thirty years there was an almost universal disposition to admit any person, not notoriously unfit, who had read a few law books. Traditionally, admission was by order of court after a committee of the bar had given a perfunctory examination. In most states this laxity on the part of courts led to reform through legislation which created examining boards.

The older indifference to the subject gradually came into conflict with the growing sense that the profession was losing ground in critical estimates. Yet it could point to its aggrandizements of power in extra-professional activities, such as legislating, holding public office, and manipulating political machinery. Probably this extra-professional power itself occasioned some alarm and fostered the criticism which induced the bar to take note of its direction of drift.

The creation of state examining boards marked a great step forward, for it centralized responsibility in officers who were impersonal and relatively independent. The state supreme court was relieved of a duty which it could not easily perform. The bar, without realizing the fact, had gained possession of the gateway to the profession.

\section{Standards for Legal Education}

Beginning fifty years and more ago, law schools arose in this country in response to the popular concern for legal education in a polity which gave the lawyer such a heavy rôle. The schools have increased and developed along two main lines. The endowed schools and those supported by state funds have been free to impose higher standards of scholarship. The stand- 
ard among them today is three years of technical study following two of general college study, though not all have yet reached this level. As their requirements for admission and graduation were increased, the proprietary schools had left to them a larger field and one sufficiently lucrative to call into being a number of such institutions. Competition between them induces considerable advertising, which tends to promote legal study.

While about 40 per cent of the law schools provide excellent courses, and it is possible for the exceptional student to get a fair education in an inferior school, the result generally has not been what is needed. A degree is nowhere a requisite to admission to practice and in many states the examinations are still too easy. The well-schooled college graduates are in a minority among those coming to the bar. In some states a high school education is not required and in no state is a single year in college necessary. We have now, as always, a great many lawyers who are ethically and professionally capable, but who have no general learning. Their ignorance of political science is a national misfortune. For a scientific view of human affairs they substitute and cling to outworn legal dogmas. For many of them history began with the discovery of America. The dogmatic, rather than the scientific view of law, dominates the profession and the bench.

For nearly thirty years the American Bar Association struggled with the problems involved in educational requirements. Gradually the tie between good education and good morals became obvious. In 1921 the Association made its pronouncement. A committee, headed by Mr. Elihu Root, reported a resolution in favor of two years of study in a college and three years in a law school as the minimum standard for admission to practice. After notable debates, the standard was adopted in the Section on Legal Education and then by the Association by large majorities.

The resolution provided also for the calling of a national conference to consider means for establishing the standard by force of law or supreme court rule in the various states. The Conference of Bar Association Delegates afforded the needed machinery and a meeting was called for February, 1922, in the city of Washington. A great deal of hostility must be overcome before there can be any general acceptance of the standard. Opposition comes from lawyers who look upon educational standards as a reflection on their own shortcomings, and from the proprietary schools. The latter, however, conceded most of the fight at the start, making a stand only for an "equivalent" to two years of college study. Victory will come first in states which have no proprietary schools but good public universities.

\section{Regulation of Conduct by the Bar ITSELF}

There remains, finally, the matter of continuing regulation of conduct by the bar itself. No other agency can avail. Nor can an unorganized or partially organized bar accomplish this. A good start has been made by the voluntary, exclusive, minority associations. But very generally throughout the country disciplinary work is weak and uncertain. In small centers the ethically sensitive are too close to offenders to be able to grip the situation. It is safer to pass by on the other side. In the large cities the occasional penalties imposed are too rare to be strongly deterrent, and they lack the needed direction toward the delicate relations of attorney to client and advocate to judge. 
There would be little reason for optimism on this score were it not for a movement for inclusive bar organization fathered by the Conference of Bar Association Delegates. In 1920 a committee, headed by Judge Clarence N. Goodwin, reported a plan for organizing the bar of a state on an inclusive and democratic basis. It starts with the proposition that the bar constitutes a body politic and that it is necessary only to provide for it a simple scheme of government by statute or by rule of the state supreme court. It is proposed that every practising lawyer in the state be required to contribute annually to the expense of the association and in return for that be given an equal and practical share in its management. 'This control is effectuated by requiring the lawyers in each district, or circuit, to elect, by mail ballots, their representative on the board of governors. This board is to exercise disciplinary powers and such other powers as may be pertinent. It can create grievance committees for cities, or counties or districts and provide means for their work.

It would be the duty of such a committee to investigate all complaints, either from laymen or lawyers, and to take such action as may be needed. The protection of the innocent is quite as important as the punishment of the delinquent. This can be done more effectually by a committee than by any court, which must necessarily act publicly. Its hearings would be quasijudicial and it would determine the facts and make a record. The committee would also have the power to compel the attendance of witnesses and the production of evidence. The accused, if found guilty of improper conduct, could accept the penalty imposed, resign, or demand review by the supreme court.
This would afford the ideal machinery, impersonal in character, sustained by a representative state body, able to protect innocent persons through privacy and to discipline offenders by publicity. The courts would accept assistance of this kind. Such a system means democratic self-government and self-discipline on the part of the bar. Every lawyer is given equal representation with no requirement save that he pay the annual dues, in default of which he must cease practising. There can be under such a plan no large element escaping responsibility by refusing to do its share, and no element contributing without a genuine voice in affairs. The governors would inevitably be representative of the best elements in the profession; not so impossibly lofty as the reformers, but assuredly jealous for the reputation of the profession thus placed in their keeping.

At the 1921 meeting of the Conference of Delegates, Chairman Goodwin was able to report that a large number of state associations were interested in the proposal and that in several states bills had been introduced in legislature. In North Dakota the first legislative result was secured. The presumption is that the voluntary associations will merge in the inclusive bar and that their social activities and interest in general legal topics will continue as formerly. This is not especially important because the existing associations might retain their present work and selective memberships, leaving to the organic bodies the functions which they are not adapted to exercise.

\section{Possibilities for Law Teachers}

An account of the American bar would be incomplete without reference to the growing importance of the professional law school teachers. The practising lawyer who teaches occa- 
sionally fills a useful part and will not soon be displaced, but there was little improvement in legal education until it was taken over by lawyers who had no conflicting interests. The past generation has seen the development in this country of the best law schools in the world, side by side with some of the least worthy, in this respect paralleling the profession, which also reaches the two extremes. Probably our best lawyers are the ablest lawyers the world has ever seen, and there can be little doubt that our worst lawyers are far below the lowest in other civilized countries. Nowhere else is there a class of lawyers comparable with the shysters of the criminal courts of this country.

'To return to the professional teachers; they are doing vastly more than creating a method of pedagogy. Their detachment from clients peculiarly fits them to deal abstractly with law. Their critique of decisions is wholesome and helps to systematize the ideas of practitioners and judges. They would do well to hold themselves less aloof from legislation, which is the most conspicuous phenomenon of modern times.

There is reason for thinking that this teaching class, constituting now, with the practitioners and judges, a third estate in the profession, is to perform a work far beyond present conceptions. We are drifting toward a situation which calls for some heroic work in respect to law. To some it appears as a "restatement" of the law; to some, as a partial codification; to others, scientific legislation. Heretofore there has been no agency for such great service. It is becoming evident that the law teachers will be best fitted to function in this field. And to this end there is needed imperatively a study of jurisprudence in order that a lasting foundation may be laid for the most difficult and far-reaching work that lawyers have ever undertaken.

\section{Present Theories and SPECUlations}

It is apparent that this article could not have been written even a year or two ago. There are at present other theories and speculations which deserve consideration. The lawyer working under annual salary, whether for a municipal corporation, a bank, trust company, insurance company or large firm of lawyers, presents a problem as yet hardly realized. Such a lawyer cannot be as closely attached to the court in which he practises as to his employer. This is not an ideal situation. Since responsibility for ethical conduct must rest upon the lawyer's personal reputation he should be a free agent, subject only to professional guidance and surveillance, and free from moral overstrain. Nor should lay agencies participate, directly or indirectly, in the practice of law, either by advising clients or by prosecuting their suits, because they cannot, like the individual lawyer, offer the sanctity of a personal reputation which compares with the ready assets which our banking laws require. A corporation cannot be disbarred.

The cost of a thorough legal education is worrying some persons who hold that it will bar applicants of small means and make for a plutocratic bar. They propose to divide the profession into two classes : on one side, thoroughly educated lawyers with general powers and functions, and on the other, partly educated lawyers with limited powers. The suggestion that the less educated might suffice to counsel the poor is so dangerous that it must be condemned outright. The poor, the ignorant, the unsophisticated most need all the protection that can be thrown about them. Low grade legal 
services are emphatically not the cheapest.

Worry about improving legal education derives partly from the belief that the inferior law schools are too strongly intrenched to be ousted or reformed. This remains to be seen. As for a division of the bar, it is submitted that the only division conceivable is one between counselors and advocates. But this cannot grow out of two kinds of law schools. It is possible that in time advocacy will emerge as a recognized specialization in a bar of greater solidarity than now exists, just as the College of Surgeons emerged from the American Medical Society. But in such case the advocate would have to rely on superior ability to try cases. There is no prospect that the general practitioner will ever be deprived of his traditional power to conduct litigation.

There is another way in which these difficulties might be resolved. It lies in encouraging the study of law, not with a view to serve clients, but to fill the places now taken by "house lawyers" in private employment. A new designation would have to be found for this class. They would not be entitled to perform any of the essential functions of the lawyer. They would be ineligible to judicial office. Their education would not be a matter of great public concern. This would preserve a field for inferior law schools, subject to competition from the universities which have added special law courses for students in commerce, transportation and executive training. It is a good thing to have a knowledge of law widespread in the community, providing the rights of clients are not jeopardized. This "outer bar" would be as favorably situated to hold public offices as is the lawyer himself and thus the imagined danger of an aristocracy of brains and knowledge monopolizing statecraft and legislation would be laid.

But whatever the outcome we must aim to establish such standards of education and ethics that the word lawyer will always and everywhere signify genuine competence and absolute fidelity. This is no mere counsel of perfection. It is entirely practical. And as we progress we will be looking toward a golden age when the legal profession will be useful and respected to a degree now barely foreshadowed.

\section{Unlawful Practice of the Law Must Be Prevented}

\section{By Julius Henry CoHeN}

Counsellor-at-Law, New York City, Author of Law and Order in Industry, and The Law: Business or Profession; Chairman, Committee on Unlawful Practice of the Law and Member,

Committee on Professional Ethies, New York County Lawyers' Association.*

\section{Chester S. LORD, Chancellor} of the Board of Regents of the University of the State of New York,

* Mr. Cohen is also author of Commercial Arbitration and the Law (Appleton-19); and of An American Labor Policy (Macmillan-19). He contributed to the Annals in September, 1917, ("Administration of Business and Discipline by the Courts") and in July, 1920 ("Collective Bargaining and the Law as a Basis for Industrial Reorganization"). The Editor. said in an address to the Chamber of Commerce of the State of New York on February second last: "Quack doctors and quack dentists have been driven from the state. The regents are called on constantly to prosecute illegal practitioners and to revoke licenses for law violation."

He reminded us that "not so very long ago no educational test was re- 